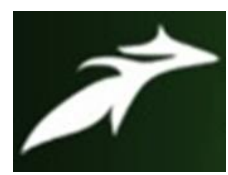

S FIONA JACQUELINE et al, International Journal of Advances in Agricultural Science \& Technology,

Vol.8 Issue.11, November-2021, pg. 52-59

ISSN: 2348-1358

Impact Factor: 6.057

NAAS Rating: 3.77

\title{
ADOPTION OF IMPROVED FARM PRACTICES IN MAIZE BY THE FARMERS OF NUAPADA DISTRICT OF ODISHA
}

\author{
S FIONA JACQUELINE* \\ M.Sc. Ag. (Agricultural Extension \& Communication)* \\ Dr. Syed H. Mazhar** \\ Associate Professor, Department of Agricultural Extension \& Communication, SHUATS, Prayagraj, Uttar Pradesh** \\ Dr. Dipak Kumar Bose*** \\ Associate Professor, Department of Agricultural Extension \& Communication, SHUATS, Prayagraj, Uttar Pradesh*** \\ Prof. (Dr.) Ms. Jahanara**** \\ Professor and Head, Department of Agricultural Extension \& Communication, SHUATS, Uttar Pradesh**** \\ DOI: 10.47856/ijaast.2021.v08i11.006
}

\begin{abstract}
Maize (Zea Mays L.) is considered as a unique cereal crop for its diversified use and suitability under various cropping systems. In India it is the third largest cereal crop in terms of acreage. The present study was conducted in Khariar block of Nuapada district of Odisha. Descriptive research design was followed, since the present study is fact-finding and present description of the respondents as well as the area. There are 117 villages in the selected block out of that 12 villages were selected through Random sampling based on existence of Maize cultivation. From the above analysis, it was concluded that majority (85.00\%) of respondents were male. Majority (45.00\%) of the respondents belonged to both the age group of (20-35) years and (36-55) years. Majority (80.00\%) of respondents were married. Majority (70.00\%) of respondents were having annual income more than 51,000. Majority (35.00\%) of respondents were having education qualification up to High School. Majority (60.00\%) of respondents were having land holding of 1-2 hectare. Majority (75.00\%) of respondents were occupation Maize Farming and other crops farming collectively. Majority (80.00\%) of respondents were having joint family. Majority (65.00\%) of respondents were having family size of more than 5 members. Majority (45.00\%) of respondents were having semi-cemented house. Majority (40.00\%) of respondents were having social participation in Farmers Society. Majority (65.00\%) of respondents daily used mobile. Majority (70.00\%) of respondents were having maize farming experience up to 1 20 years. Majority (45.00\%) of respondents were having medium level knowledge regarding Maize Cultivation Practices. Majority the adoption of Improved Production Technology of Maize was found to be high that is 75.00 percent. According to the response from the respondents, non-performance of visit by agricultural personnel time to time ranked I for constraints faced by the respondents, Lack of hybrid seed ranked II, Lack of credit facility at time ranked III, Lack of proper resources and capital ranked IV and so on. According to the suggestions received from the respondents, Hybrid seed should be available in time, Credit should be available earlier and timely, Availability of fertilizers and other inputs should be in time, Technical advice and training should be given at right time and so on.
\end{abstract}

Keywords: Maize, Farmers, Adoption, Improved farm practices etc. 


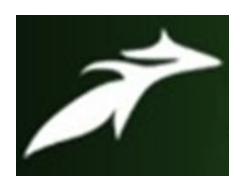

S FIONA JACQUELINE et al, International Journal of Advances in Agricultural Science \& Technology, Vol.8 Issue.11, November-2021, pg. 52-59

ISSN: 2348-1358

Impact Factor: 6.057

NAAS Rating: 3.77

\section{Introduction}

Maize (Zea Mays L.) is considered as a unique cereal crop for its diversified use and suitability under various cropping systems. In India it is the third largest cereal crop in terms of acreage. India is one of the top 10 maize producers in the world; it contributes around 2$3 \%$ of the total maize produced globally and is one of the top-5 maize exporters in the world contributing almost $14 \%$ of the total maize exported to different countries around the world. South-East Asia is the biggest market for Indian maize with almost $80 \%$ of the exported Indian Maize going to Indonesia, Vietnam and Malaysia. After rice and wheat, maize is the third most important field crop in India. Maize has three growing seasons in India, namely Kharif, Rabi and Spring. Kharif is the most important season covering around $80 \%$ of the total area of maize in India. It also produces around $70 \%$ of the total Indian maize. Rabi is the second most important season that covers around $15 \%$ of total area of maize. The yield for maize crop varies by region where climatic conditions are different, e.g., Rabi maize produced in Andhra Pradesh and Bihar has higher yield than what Kharif farmers get elsewhere. Maize is being used in different sectors and activities in India. The biggest user of Maize in India is the poultry industry with $47 \%$ of the share followed by direct consumption at $20 \%$. Other usages include cattle feed (14\%) and starch (14\%) followed by the food and beverage industry with a 7\% share. Maize is the world's leading crop and is widely cultivated as cereal grain that was domesticated in Central America. Globally, maize is known as queen of cereals because of its highest genetic yield potential. Maize is the only food cereal crop that can be grown in diverse seasons, ecologies and uses. Lack of nitrogen $(\mathrm{N})$ fertilizer is the greatest limitation on maize production in the savannas of WCA (Carsky and Iwuafor, 1995). In most cases, less than $20 \mathrm{~kg}$ per ha of $\mathrm{N}$ fertilizer is applied to the Maize crop. The amount and distribution of rainfall are highly important factors in successful maize production. The amount of rainfall determines the growth and yield of maize especially where irrigation is not feasible. Maize has many types like normal yellow/ white grain, sweet corn, baby corn, popcorn, waxy corn, high amylase corn, high oil corn, quality protein maize, etc. Apart from this, maize is an important industrial raw material and provides large opportunity for value 


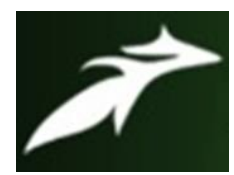

S FIONA JACQUELINE et al, International Journal of Advances in Agricultural Science \& Technology, Vol.8 Issue.11, November-2021, pg. 52-59

ISSN: 2348-1358

Impact Factor: 6.057

NAAS Rating: 3.77

addition. Maize belongs to the tribe Maydeae of the grass family Poaceae. "Zea" was derived from an old Greek name for a food grass.

\section{Objective}

- To find out the adoption of Improved Farm Practices by Maize Farmers.

\section{Research Methodology}

The present study was conducted in Khariar block of Nuapada district. Descriptive research design was used for the present study because the present study is fact-finding and present description of the respondents as well as the area. There are 117 villages in the selected block out of that 12 villages were selected through Random sampling based on existence of Maize Farming. A total number of 120 respondents were taken from 12 villages through purposive sampling, 10 respondents from each village were selected for the study. Since the respondents were Maize Growers so 10 growers from each village were selected through purposive sampling. The study was based on primary \& secondary data. The data was collected personally by the researcher through pre-tested interview schedules. Data analysis was done through frequency and percentage distribution using statistical tools.

For calculating percentage, frequency was multiplied by 100 and divided by total number of Respondents.

$$
\mathrm{P}=\mathrm{Y} / \mathrm{Nx} 100
$$

Where,

$\mathrm{P}=$ Percentage

$\mathrm{X}=$ Frequency of the Respondents

$\mathrm{N}=$ Total number of Respondents 


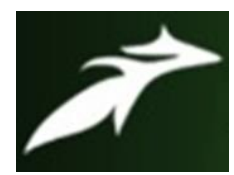

S FIONA JACQUELINE et al, International Journal of Advances in Agricultural Science \& Technology, Vol.8 Issue.11, November-2021, pg. 52-59

Results \& Discussion

Table 1. Distribution of respondents according to the adoption of Improved Production Technology of Maize:

\begin{tabular}{|c|c|c|c|c|c|}
\hline S.No. & $\begin{array}{l}\text { Recommended } \\
\text { improved production } \\
\text { practices }\end{array}$ & Response & & & $\begin{array}{l}\text { Total number } \\
\text { of } \\
\text { Respondents }(\mathrm{N})\end{array}$ \\
\hline & & FA & PA & NA & \\
\hline 1. & Varieties sowing & $06(05.00)$ & $90(75.00)$ & $24(20.00)$ & 120 \\
\hline 2. & Sowing time & $18(15.00)$ & $78(65.00)$ & $24(20.00)$ & 120 \\
\hline 3. & Sowing by driller & $30(25.00)$ & $60(50.00)$ & $30(25.00)$ & 120 \\
\hline 4. & Seed treatment & $12(10.00)$ & $90(75.00)$ & $18(15.00)$ & 120 \\
\hline 5. & Seed rate & $30(25.00)$ & $66(55.00)$ & $24(20.00)$ & 120 \\
\hline 6. & $\begin{array}{lll}\begin{array}{l}\text { Source } \\
\text { material }\end{array} & \text { of } & \text { seed } \\
\end{array}$ & 108(90.00) & $06(05.00)$ & $06(05.00)$ & 120 \\
\hline 7. & $\begin{array}{l}\text { Method of } \\
\text { followed }\end{array}$ & 84(70.00) & $12(10.00)$ & $24(20.00)$ & 120 \\
\hline 8. & Spacing adopted & $96(80.00)$ & $12(10.00)$ & $12(10.00)$ & 120 \\
\hline 9. & $\begin{array}{l}\text { Chemical fertilizer and } \\
\text { manure management }\end{array}$ & $96(80.00)$ & $18(15.00)$ & $06(05.00)$ & 120 \\
\hline 10. & Inter cultivation & $06(05.00)$ & $108(90.00)$ & $06(05.00)$ & 120 \\
\hline 11. & Weed management & $102(85.00)$ & $12(10.00)$ & $06(05.00)$ & 120 \\
\hline 12. & $\begin{array}{ll}\text { Plant } & \text { protection } \\
\text { measure } & \end{array}$ & 12(10.00) & $102(85.00)$ & $06(05.00)$ & 120 \\
\hline 13. & Yield & $84(70.00)$ & $36(30.00)$ & $00(00.00)$ & 120 \\
\hline
\end{tabular}




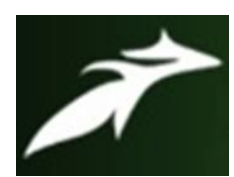

S FIONA JACQUELINE et al, International Journal of Advances in Agricultural Science \& Technology, Vol.8 Issue.11, November-2021, pg. 52-59

ISSN: 2348-1358

Impact Factor: 6.057

NAAS Rating: 3.77

\section{From this Table-1 Major finding of improved production technology of Maize are:}

- Majority of respondents (75\%) have partially adopted the recommended improved cultivation practices of Varieties sowing.

- Majority of respondents (65\%) have partially adopted the recommended improved cultivation practices of Sowing time.

- Majority of respondents $(60 \%)$ have partially adopted the recommended improved cultivation practices of Sowing by driller.

- Majority of respondents (75\%) have partially adopted the recommended improved cultivation practices of Seed treatment.

- Majority of respondents (55\%) have partially adopted the recommended improved cultivation practices of Seed rate.

- Majority of respondents (90\%) have fully adopted the recommended improved cultivation practices of source of Seed material.

- Majority of respondents (70\%) have fully adopted the recommended improved cultivation practices of method of Sowing followed.

- Majority of respondents (80\%) have fully adopted the recommended improved cultivation practices of Spacing adopted.

- Majority of respondents (80\%) have fully adopted the recommended improved cultivation practices of Chemical fertilizer and manure management.

- Majority of respondents $(90 \%)$ have partially adopted the recommended improved cultivation practices of Inter cultivation.

- Majority of respondents (85\%) have fully adopted the recommended improved cultivation practices of Weed management.

- Majority of respondents (85\%) have partially adopted the recommended improved cultivation practices of Plant protection measures.

- Majority of respondents (70\%) have fully adopted the recommended improved cultivation practices of Yield. 


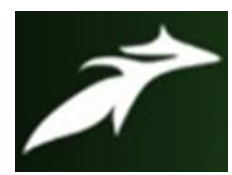

S FIONA JACQUELINE et al, International Journal of Advances in Agricultural Science \& Technology, Vol.8 Issue.11, November-2021, pg. 52-59

Table 2. Distribution of respondents based on level of adoption of Improved Production Technology of Maize.

\begin{tabular}{|l|l|l|l|}
\hline S.No. & Category & Frequency & \%age \\
\hline 1. & Low (5-10) & 24 & 20.00 \\
\hline 2. & Medium (11-16) & 6 & 06.00 \\
\hline 3. & High (17-21) & 90 & 75.00 \\
\hline & TOTAL & $\mathbf{1 2 0}$ & $\mathbf{1 0 0 . 0 0}$ \\
\hline
\end{tabular}

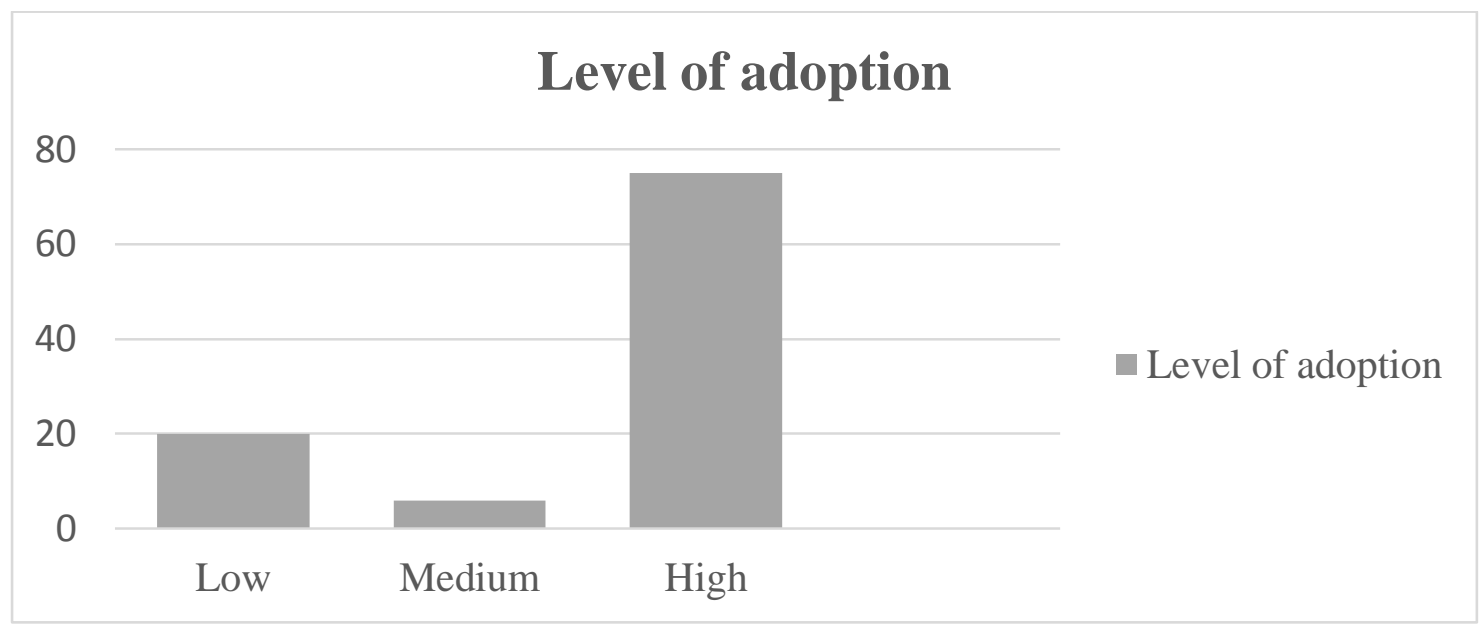

Figure 1. Level of adoption of the respondents

From the above table- 2 and figure- 1 it is concluded that the level of adoption of Improved Production Technology of Maize is high $75.00 \%$ followed by low $20.00 \%$ and medium $06.00 \%$. 


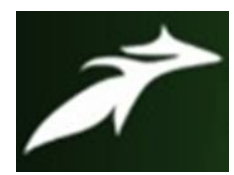

S FIONA JACQUELINE et al, International Journal of Advances in Agricultural Science \& Technology, Vol.8 Issue.11, November-2021, pg. 52-59

ISSN: 2348-1358

Impact Factor: 6.057

NAAS Rating: 3.77

\section{Conclusion}

It is therefore concluded that majority of respondents were both young and middleaged people, having education up to high school and mostly dependent on Maize farming and other crops farming collectively for their income. Majority of respondents were having total land holding of 1-2 hectare. Partial respondents were having temporarily social participation in farmers society and majority of them were having Maize Farming Experience up to 10-20 years. Majority of respondents were having medium level of knowledge regarding Maize Cultivation Practices. The adoption of Improved Production Technology of Maize was found to be high.

The major constraints faced by the respondents were non-performance of visit by agricultural personnel time to time, lack of hybrid seed, lack of credit facility at time, lack of proper resources and capital and lack of training programme related with improved practices. They have suggested that hybrid seed should be available in time, credit should be available earlier and timely, availability of fertilizers and other inputs should be in time, technical advice and training should be available in right time, the proper plant protection measures should be given. The country produces 21.81 million tonnes of maize from $8.69 \mathrm{~m}$ ha of area with a productivity of $2509 \mathrm{~kg} / \mathrm{ha}$. Evidently, Agriculture plays a critical role in the economy of the state and livelihood of majority of its populace.

\section{References}

[1]. Aienembabazi J. (2014), The Role of Farming Experience on the Adoption of Agricultural Technologies.

[2]. Bhadauria (2013), Effect of Mulching Practices, Varieties and Fertility Levels on Physiological Growth Parameters of Maize, International Journal of Current Microbiology and Applied Sciences special Issue-6 pp. 2781-2786

[3]. Chodon N., Iftikar W. (2021), The Transformative Value of Maize.

[4]. Dass and USDA (2013) Maize production systems for improving resource-use efficiency and livelihood security, Directorate of Maize Research, Pusa Campus, New Delhi- 110 012, 123p. 


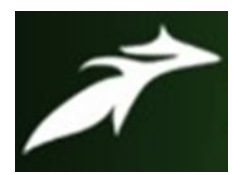

S FIONA JACQUELINE et al, International Journal of Advances in Agricultural Science \& Technology, Vol.8 Issue.11, November-2021, pg. 52-59

ISSN: 2348-1358

Impact Factor: 6.057

NAAS Rating: 3.77

[5]. Dhaka. B, Meena B.\& Suwalka R. (2017) Popularization of improved maize production technology through frontline demonstrations in south-eastern Rajasthan, Journal of Agricultural Sciences, Vol 01, P.39-42

[6]. Donovan. M (2020) (Adoption of Conservation Agriculture Practices), CIMMYT, January 23

[7]. Dutta S., Chakraborty S., Goswami R., Banerjee H., Majumdar K., Li B. \& Jat M. (2020), Maize Yield in Smallholder Agriculture System-An Approach Integrating Socio-Economic and Crop Management Factors.

[8]. Foster, Andrew and Rosenzweig M., (2010), "Technical Change and Human Capital Returns and Investments: Evidence from the Green Revolution," American Economic Review, September. 2010 